\title{
National Brand Identity: Pilot Study on Perception of Croatian Student Population
}

\section{Sanja Seljan}

Faculty of Humanities and Social Sciences, Information and Communication Sciences, Zagreb Croatia

Sara Horvat

Faculty of Humanities and Social Sciences, Information and Communication Sciences, Zagreb Croatia

Berislava Starešinić

Privredna banka d.d., Croatia

\section{Abstract}

A message sent to a specific market or an audience contains certain types of information that affect the audience. For this reason, brand identity, nowadays increasingly in a digital form, plays an important role. Each state wants to create a robust, attractive, and different brand identity that will set it apart from other states and thus augment its reputation. This research aimed to determine the elements of brand identity that respondents mostly associate with Croatia and to examine their attitudes towards the belief that the brand identity that influences emotions is essential in the creation of national visual identity, as well as their attitudes towards the assumption that the brand identity of Croatia should be liked first by the inhabitants of Croatia, and only then by foreign tourists. Two research propositions were tested using the structural equation modeling, measuring the relationship between the emotional and formal elements of brand identity with the attitudes towards the emotions concerning the brand identity and the relevance of the brand identity to the country residents.

Keywords: branding, nation, brand identity, Croatia, reputation, structural equation modeling, visual brand identity, information

JEL classification: M3

Paper type: Research article

Received: Apr 23, 2021

Accepted: Aug 11, 2021

DOI: 10.54820/UTSQ4691 


\section{Introduction}

Companies make a permanent identity through branding, including its quality, values, reputation, and mission (Kesić et al., 2010). Branding encompasses practice by which the company creates a picture, symbol or design that identifies the company and distinguishes it from others on the market. Brand perception simulates customers' feelings of trust and welfare, and good brand perception can influence consumers' behavior and quality expectations, augment confidence and drive to new business opportunities. The alignment of human interest and brand perception is measured through continuous monitoring (Kervyn et al., 2012).

Visual elements represent the central part of branding. Therefore, professional, easy-to-remember, and appealing design can help build a positive relationship with existing and, potentially, new customers (Fajardo et al., 2016). Consistent and careful use of branding elements through traditional and online media can shape consumers' expectations. Visual assets of branding which appear consistently, including logo, font, typography, color, and website design, represent powerful branding tools (Stoimenova, 2017).

Each country has unique characteristics by which it is recognizable in the world, while the nation branding allows each state's unique attributes to be applicable on the market (Ipsos, 2020b; Volos, 2019; Roth et al., 2008) and to create positive destination image (Kesić et al., 2010; 2004), since the mental representation of the tourist destination is influenced by physical object/realities, beliefs, and feelings (Martin et al., 2008). Information elements appearing in various nation brand identity solutions belong to various categories: history, culture, sport, health, nature, symbols, persons, specific industry, lifestyle, etc.

This research aims to analyze information features in the nation brand identity branding. The paper gives an overview of several examples of successful nation branding, followed by a description of the Nation Brand Index (NBI) - an analytical tool used to assess the nation brand index (Ipsos, 2020a). The research presents the results of a survey conducted among the student population on the information characteristics of the Croatian branding.

The goal of this study was to find out which aspects of brand identity respondents most associate with Croatia, as well as to investigate their attitudes toward the belief that brand identity that influences emotions is significant in the creation of national brand identity, as well as their attitudes toward the impression that Croatia's brand identity should be liked first by the inhabitants.

After the Introduction, the chapter Literature review is presented, related to the reputation as the basis for branding, the concept of nation branding, and the Nation Brand Index (NBI) - analytical tool for measuring nation brands. The following chapter, methodology, gives information on the aim of the research, sample, and methodology, including research instrument and research propositions. The chapter results bring answers of the research instrument and results of the research statistics, including the Shapiro-Wilk test - a test of normality, descriptive statistics for variables Q1-Q7, Principal component analysis (PCA) for reducing the dimensionality of the dataset, i.e., to extract elements defining the country's brand image, the correlation analysis among all variables contained in the research instrument and the structural equation modeling to test the two research propositions. In the end, the conclusion is given together with suggestions for further research. 


\section{Literature review}

\section{Reputation as the Basis for Branding}

Reputation has been primarily considered in terms of corporations. Fombrun et al. (1997) were the first to attempt to systematize the terminology of corporate reputation. Starting from corporate identity and image, Fombrun et al. (1997) propose a definition of corporate reputation. On the one hand, the corporate identity reflects the company's perception by employees and managers. It includes critical characteristics that distinguish the company from the competition and continuously link past present and future results.

On the other hand, the corporate image reflects the perception of interest groups outside the company. It is considered a consequence of public relations, marketing, and other organizational processes that shape people's perception of the company (image). A company may seek to moderate its corporate image, but the result will be influenced by publicity, regulation, industrial characteristics, and other external factors. According to Fombrun (2001), a new comprehensive and refined definition of reputation is used, stating that it includes the economic value (reputation capital), image (representation), and assessment of the quality of the company.

Barnett et al. (2006) search the literature to provide an overview of definitions of corporate reputation. Based on an analysis of 47 statements, they define three primary groups of definitions of corporate reputation: reputation as recognition, reputation as business valuation, and reputation as economic value. Recognition implies using language that symbolizes how the company is recognized in interest groups, but without a direct positive or negative assessment. Definitions that belong to the assessment group define the company's status as an assessment, which implies a kind of attractiveness. Finally, the definition of a reputation as an asset refers to an enterprise's intangible or economic value, with the latter group of definitions dealing primarily with the implications of reputation.

Divergent corporate behavior and social expectations are a significant source of corporate reputation risk. As quoted in Grgić (2012), Roberts et al. (2002) list four basic categories of relational reputation: corporate governance, environmental protection, employee rights, and product safety. Lee et al. (2009) believe that these categories are significant for those companies that associate with corporate social responsibility, which enables the creation and maintenance of trust with stakeholders, and ultimately affects raising capital, creating a network of business partners and increasing sales.

Companies and other organizational entities are not the only ones who need to maintain their reputations. Indeed, states are becoming increasingly worried about their reputation concerning other nations and are actively measuring and managing it (Passow et al., 2005), while Kang et al. (2010) investigate the relationship between the country reputation and the overall corporate reputations of a country on international consumers' purchase intention.

Country reputation refers to perceptions of a country, shared by domestic and international publics, based on personal experience and information received. Images of a country are on a continuum between 'personal' to 'public' images, depending on the extent to which images of a country are publicly shared or peculiar to the individual (Kang et al., 2010).

People often form judgments about numerous aspects of a country, like the country's politics, economy, or culture, based on images of the country rather than direct experience of these faraway places (Kang et al., 2010). 


\section{Nation Branding}

Nation branding is still a term that has not been fully explored and is in the early stages of its existence. To fully understand the concept of nation branding, it is necessary to define the term brand. According to the American Marketing Organization (2021), a brand is a name, title, sign, symbol, or design along with their combination, which has the purpose of recognizing the goods and services of a particular manufacturer or group of them and distinguishing them on the market from others. Branding includes various elements, such as logo, design (print design, website design), motto, tone of voice, style, mission statement, company values, attitudes toward health, nature, etc. It creates a perception of the company in other minds.

According to Johnson (2020), brand identity shapes perception and creates an impression through visible elements of the brand. The information features, such as natural landscape, buildings, fashion, food, famous persons, etc., play an essential role in branding.

Johnson (2020) emphasizes that images are a powerful form of communication, and with the power of communication comes the great responsibility to ensure that the sent message is adequately understood. A message sent to a specific market or an audience contains certain types of information that affect the audience.

Handayani et al. (2013) point out that one of the biggest challenges is communicating nation brand image to various audiences in different countries, which is multifaceted and developed through the management of the national brand image. The authors define the nation brand image as "the total collection of a nation's multifaceted images that are associated with a country's national dimensions and activities which are managed by a country's government based on the actual image, national identity and desired future image to be perceived by international audiences".

The brand identity of a country plays an essential role in the international market, according to Fan (2006). According to the annual report on the most valuable national brands (Brand Finance, 2020), the United States, China, and Japan are the three most valuable nation brands. The three strongest national brands are Germany, the United Kingdom, and Switzerland.

Dinnie (2016), in his book "Nation Branding", points out the investment of government in nation branding to improve country's influence, tourism, investment, trade, giving examples of specific countries, such as the United Arab Emirates, China, Great Britain, India, Cuba, and others. The author defines a national brand as a unique, multidimensional blend of elements that provide a nation with culturally based differentiation and relevance to its target audiences. According to Dinnie (2016), there is an awareness that a brand exists in the consumer's mind and that marketing cannot be controlled entirely.

The essence of good nation branding is that every nation is a brand, and every country has built its brand at some point. The nation's brand could have emerged by chance through word of mouth, products, education, or contact with people (Loo et al., 2006). Good nation branding enables recognisability, competitiveness, and attracting the desired group. According to Aronczyk (2008), the population has a crucial role through living the brand.

Zhouxiang (2020) gives an example of China which presents itself as an Asian global leader, differentiating from others by developing "Chinese identity "through national specific characteristics, such as character letter of the written language, as a technological giant and global electronic player moving towards artificial intelligence and digitization, identity characterized by self-esteem and family ties 
(image of spirituality, respect, and personal growth), productiveness, responsibility, and respect (the notion of subordination), being part of the nature (the idea of harmony and nature connection), among others.

Stoimenova (2017) elaborated design elements of the visual brand identity through essential elements and communication products, such as stationery, advertising, corporate materials, products, vehicles, equipment, etc.

As a branding example, Papp-Váry (2018) gives the example of Estonia. The small country with about 1.3 million inhabitants, this country in 2018. celebrated the 100 years of independence. The starting point of Estonia's branding was to determine where Estonia as a country can thrive. The Estonian government has realized that Estonia has a wood industry, forests, and machinery industry, but this does not compete. Therefore, they focused on developing electronics and information technology. Until 1997, all classrooms in the state were equipped with computers, while until 1998, all computers had Internet access. The digital revolution of the state happened not only because of technology but because of branding the state as a citizen-friendly state that provides all services online (Papp-Váry, 2018).

Papp-Váry (2018) points out three phases in the nation branding:

- $\quad$ 1st phase: "We are here!" when Estonia presented itself to Europe and the world

- 2nd phase: "We are normal!" before entering the EU when the country wanted to show itself as sharing common values and having excellent students

- 3rd phase: "We are special!" presented specific characteristics that differentiate the country from others.

After winning the contest of the Eurosong in 2001, it started with logos "Estonia positively surprising" and "Welcome to Estonia". The country wanted to identify advancement domains: electronics and information technology, and as citizenfriendly with different kinds of online services (Papp-Váry, 2018). The government developed the e-banking system in 1996., in 2000 them-parking, in 2001. x-road, in 2002. e-ID and digital signature, in 2005. e-voting. The development of the digital concept had changed the branding strategy. The country presented itself as the one with pure and untouched nature which exists simultaneously with digitally advanced society. According to Papp-Váry (2018), Estonia presented unique, friendly, realistic, and rich content. Estonia has proven that with consistency and continuous work on improving branding, one can be competitive regardless of the size or starting point of the branding.

One of the best-known visual codes of Croatia is red \& white cubes. Besides many other visual codes, this visual code represents the country on sport and cultural events, in logos of institutions and associations, on various occasions. The author points out the national visibility through the national identity as the whole of facts, beliefs, and values that differentiate from others. The "cubes" were afterward introduced in various company logos.

\section{Nation Brand Index (NBI)}

Nation brand identity can help in the branding of emerging countries as new destinations. Information elements appearing in various nation brand identity solutions belong to multiple categories: history, culture, sport, health, nature, symbols, persons, specific industry, lifestyle, etc.

Various survey methodologies are used to analyze the current situation on the market. One of them is the Nation Brands Index (NBI), which, similar to City Brands 
Index (CBI), represents an analytical tool that attempts to measure and rank the nation, city, or regions in the world.

Nation branding is a complex process, which according to Aronczyk (2008), consists of the following steps: evaluation, education, brand core identification, and implementation/communication. For the evaluation purpose, different methods exist. In contrast, according to the Nation Brand Index (NBI), one of the common ones is the Nation Brand Hexagon concept (Ipsos, 2020a).

Nation Brands Index gives insight into the broad international reputation of 50 nations across six dimensions:

- Exports - covering the public perception of products and services of the specific country

- Governance - including the public opinion of the national government competencies related to commitment, peace, and security, justice, environment, and poverty

- Culture and Heritage - including the perception of the nation's Heritage and gratefulness for the culture, art, film, music, and literature

- People - including reputations of the population for competencies, openness, friendliness, tolerance, and other

- Tourism - including the level of interest for the country, for natural and tourist attractions

- Investment and Immigration - including the strength to attract people to live, work and study in the country, and perception of the life quality and the business environment

The Nation Brands Index, quarterly, analyses the responses of over 25,000 respondents in 35 different countries around the world. This index helps governments, organizations, and companies to understand, measure, and ultimately build a strong national image and reputation. Results of each country are presented in the hexagon and summed up in the overall index.

According to Volos (2019), in 2019, Germany retained the first position as the top "Nation Brand ", the same as in 2018, while France moved to the second position and Canada to the third position. In 2018, the second position belonged to Japan and the third to the United Kingdom.

In 2020, top national brands suffered from the pandemic crisis, feeling significant economic impacts due to the pandemic crisis. According to Ipsos (2020a), Germany retains the first position, having a consistently strong reputation in several categories: Exports, Immigration and Investment, Culture, and Governance, while world citizens have positive feelings when buying German products. The second position is taken by the United Kingdom, while France dropped from the second position in 2019 to the fifth position in 2020. While the United States and China mark the most evident decline in NBI Index, Australia and New Zealand are marked with the most apparent improvements.

\section{Methodology}

This research aimed to analyze the attitudes about the Croatian brand identity, perceived by the student population, namely, to determine the elements of brand identity that respondents mostly associate with Croatia and examine their opinion on the development of the Croatian brand identity enables brand positioning.

The questionnaire consisted of a set of questions. The first part consisted of demographic data and affective attitudes towards the brand identity of Croatia. The second part of the questionnaire was focused on the respondent's preferences of the destination selection, accommodation, and the length of travel. The final 
piece was related to Croatia's affective attitudes towards brand identity, presented in the research results.

The research was conducted in August of 2020, using a questionnaire created on the Google forms platform. Google forms platform does not collect information about respondents in any form. The research is under the rules on personal data protection (GDPR). The questionnaire was published on several Facebook groups: Travel Advisor, Undergraduate Study of Information and Communication Sciences $2017 / 2018$, and verbally to friends and family.

The survey was conducted on 491 examinees belonging to the Croatian student population, where attitudes towards the brand identity of Croatia are examined. Out of 330 respondents, 295 were female (89\%) and 35 respondents (11\%). Results of the research are to be taken as preliminary due to a non-random sample.

Table 1

Research instrument

\begin{tabular}{|c|c|}
\hline Code & Research question \\
\hline Q1 & $\begin{array}{l}\text { I think that a country is represented mainly by buildings (as an element of the } \\
\text { country's brand identity). }\end{array}$ \\
\hline Q2 & $\begin{array}{l}\text { I think that a country is well represented by food (as an element of the country's } \\
\text { brand identity). }\end{array}$ \\
\hline Q3 & $\begin{array}{l}\text { I think that a country is well represented by fashion or a characteristic WAY of } \\
\text { DRESSING (as an element of the country's brand identity). }\end{array}$ \\
\hline Q4 & $\begin{array}{l}\text { A country is well represented by a logo, a sign, or a combination of colors (as an } \\
\text { element of the country's brand identity). }\end{array}$ \\
\hline Q5 & $\begin{array}{l}\text { A country is well represented by a natural landscape (as an element of the country's } \\
\text { brand identity). }\end{array}$ \\
\hline Q6 & $\begin{array}{l}\text { A country is best represented by the coat of arms and the flag (as an element of the } \\
\text { country's brand identity). }\end{array}$ \\
\hline Q7 & $\begin{array}{l}\text { I think that a country is represented mainly by celebrities (e.g., athletes, musicians, } \\
\text { scientists, politicians, etc.) - as an element of the country's brand identity. }\end{array}$ \\
\hline Q8 & $\begin{array}{l}\text { I believe that the brand identity that influences emotions is fundamental in creating } \\
\text { a national brand identity. }\end{array}$ \\
\hline Q9 & $\begin{array}{l}\text { I think that the brand identity of Croatia should be liked first by the inhabitants of } \\
\text { Croatia and only then by foreign tourists. }\end{array}$ \\
\hline
\end{tabular}

Source: Authors' work

The analysis was conducted using the following steps: First, data were analyzed using descriptive statistics. Second, principal component analysis was conducted on the variables Q1 to Q7 to extract elements defining the country's brand image. Third, correlation analysis has been conducted using all the variables that are contained in the research instrument. Fourth, the structural equation modeling has been undertaken to test the following research propositions:

- RP 1: Emotional elements of brand identity will be more connected to the belief that the brand identity that influences emotions is relevant in the creation of a national brand identity than the formal elements of brand identity

- RP 2: Formal elements of brand identity will be more connected to the belief that the brand identity of Croatia should be liked first by the inhabitants of Croatia, and only then by foreign tourists than the emotional elements of brand identity 


\section{Results}

\section{Elements that represent the country the most}

In the questionnaire that examines elements that primarily represent a particular country, seven parts are used: buildings, food, fashion, logo and symbol, natural landscape, emblems and flag, and famous people. The answers are scored on a Likert scale from 1-strongly disagree to 5- strongly agree.

Results of the research show, as in Table 2 that $60 \%$ of respondents strongly agree and $37 \%$ agree (together $97 \%$ ) that the natural landscape best represents the country. The second element for which $31 \%$ of respondents strongly agreed and $56 \%$ agreed (in total, $87 \%$ ) was food. The second position that $46 \%$ agreed with and $11 \%$ did strongly agree with was buildings. The natural landscape, food, and buildings were the three elements that attracted attention to the highest scores. The lowest scores (for the claim that the selected element mainly represented the country, were given to emblem/ flag, logo, and fashion.

Table 2

Perception of elements that represent the country the most

\begin{tabular}{|c|c|c|c|c|c|}
\hline Elements & $\begin{array}{l}\text { 1- Strongly } \\
\text { disagree }\end{array}$ & 2- Disagree & $\begin{array}{l}3 \text { - Neither } \\
\text { agree nor } \\
\text { disagree }\end{array}$ & 4-Agree & $\begin{array}{l}\text { 5-Strongly } \\
\text { agree }\end{array}$ \\
\hline Q1. Buildings & $5 \%$ & $14 \%$ & $21 \%$ & $48 \%$ & $11 \%$ \\
\hline Q2. Food & $1 \%$ & $2 \%$ & $10 \%$ & $56 \%$ & $31 \%$ \\
\hline Q3. Fashion & $9 \%$ & $18 \%$ & $25 \%$ & $36 \%$ & $12 \%$ \\
\hline $\begin{array}{l}\text { Q4. Logo, } \\
\text { symbol }\end{array}$ & $9 \%$ & $22 \%$ & $25 \%$ & $34 \%$ & $11 \%$ \\
\hline $\begin{array}{l}\text { Q5. Natural } \\
\text { landscape }\end{array}$ & $0 \%$ & $0 \%$ & $3 \%$ & $37 \%$ & $60 \%$ \\
\hline $\begin{array}{l}\text { Q6. Emblem, } \\
\text { flag }\end{array}$ & $12 \%$ & $22 \%$ & $25 \%$ & $26 \%$ & $15 \%$ \\
\hline $\begin{array}{l}\text { Q7. Famous } \\
\text { people }\end{array}$ & $5 \%$ & $17 \%$ & $26 \%$ & $37 \%$ & $15 \%$ \\
\hline
\end{tabular}

Source: Authors' work

Table 3 presents the results of the Shapiro-Wilk test for variables Q1 to Q7, indicating that the distribution of the variables is not following a normal distribution. Table 4 shows the descriptive statistics for variables measuring the perception of elements representing the country the most. The highest grade was given to variables Q2 and Q5, which refer to food and natural landscape, which are consistent with the overall reputation of Croatia since these are the elements that mostly attract visitors. Dispersion is moderate across all variables, with the coefficients of variation ranging from $11.1 \%$ to the highest value of $41.3 \%$ for the variable Q6 (Emblem, Flag). Data distributions are skewed to the left for all the variables.

Table 3

Shapiro-Wilk test for variables Q1-Q7

\begin{tabular}{llllllll}
\hline & Q1 & Q2 & Q3 & Q4 & Q5 & Q6 & Q7 \\
\hline Shapiro-Wilk & $0.861^{* *}$ & $0.778^{* *}$ & $0.902^{* *}$ & $0.906^{* *}$ & $0.677^{* *}$ & $0.911^{* *}$ & $0.900^{* *}$ \\
P-value of Shapiro-Wilk & $<.001$ & $<.001$ & $<.001$ & $<.001$ & $<.001$ & $<.001$ & $<.001$ \\
\hline Note: ** statistically significant at 1\% & & & & & & \\
Source: Authors' work & & & & & &
\end{tabular}


Table 4

Descriptive statistics for variables Q1-Q7

\begin{tabular}{lrrrrrrr}
\hline & Q1 & Q2 & Q3 & Q4 & Q5 & Q6 & Q7 \\
\hline Valid & 330 & 330 & 330 & 330 & 330 & 330 & 330 \\
Mean & 3.458 & 4.142 & 3.233 & 3.158 & 4.570 & 3.115 & 3.403 \\
Median & 4.000 & 4.000 & 3.000 & 3.000 & 5.000 & 3.000 & 4.000 \\
Std. Deviation & 1.040 & 0.748 & 1.147 & 1.143 & 0.554 & 1.240 & 1.082 \\
Coefficient of variation & $26.0 \%$ & $18.7 \%$ & $38.2 \%$ & $38.1 \%$ & $11.1 \%$ & $41.3 \%$ & $27.1 \%$ \\
Skewness & -0.694 & -1.070 & -0.345 & -0.239 & -0.819 & -0.105 & -0.378 \\
Std. Error of Skewness & 0.134 & 0.134 & 0.134 & 0.134 & 0.134 & 0.134 & 0.134 \\
Kurtosis & -0.143 & 2.417 & -0.734 & -0.824 & -0.383 & -0.989 & -0.575 \\
Std. Error of Kurtosis & 0.268 & 0.268 & 0.268 & 0.268 & 0.268 & 0.268 & 0.268 \\
Minimum & 1.000 & 1.000 & 1.000 & 1.000 & 3.000 & 1.000 & 1.000 \\
Maximum & 5.000 & 5.000 & 5.000 & 5.000 & 5.000 & 5.000 & 5.000 \\
\hline
\end{tabular}

Source: Authors' work

\section{Principal component analysis}

Principal component analysis was conducted to group variables measuring the perception of elements that represent the country the most. The varimax rotation and eigenvalues were used as the criteria for selecting several factors. The factor solution is statistically significant at $1 \%$ (chi-square=151.487; p-value<0.000). Two factors have been extracted: emotional elements of brand identity and formal elements of brand identity (Table 5 and Table 6), as indicated by Scree Plot (Figure 1).

Table 5

Eigenvalues for the extracted factors

Component Characteristics

\begin{tabular}{lccc}
\multicolumn{5}{c}{ Eigenvalue } & Proportion var. & Cumulative \\
PC1 & 2.104 & 0.301 & 0.301 \\
PC2 & 1.251 & 0.179 & 0.479 \\
\hline
\end{tabular}

Source: Authors' work

Table 6

Factor loadings

\begin{tabular}{lccc}
\hline \multicolumn{4}{l}{ Component Loadings } \\
\hline & PC1 & PC2 & Uniqueness \\
Q1 & & 0.640 & 0.588 \\
Q2 & & 0.788 & 0.338 \\
Q3 & & 0.501 & 0.566 \\
Q4 & 0.787 & & 0.377 \\
Q5 & & 0.535 & 0.714 \\
Q6 & 0.758 & & 0.411 \\
Q7 & 0.548 & & 0.650
\end{tabular}

Note. The applied rotation method is varimax.

Source: Authors' work 
Figure 1

Scree plot confirming the validity of the 2-factor solution

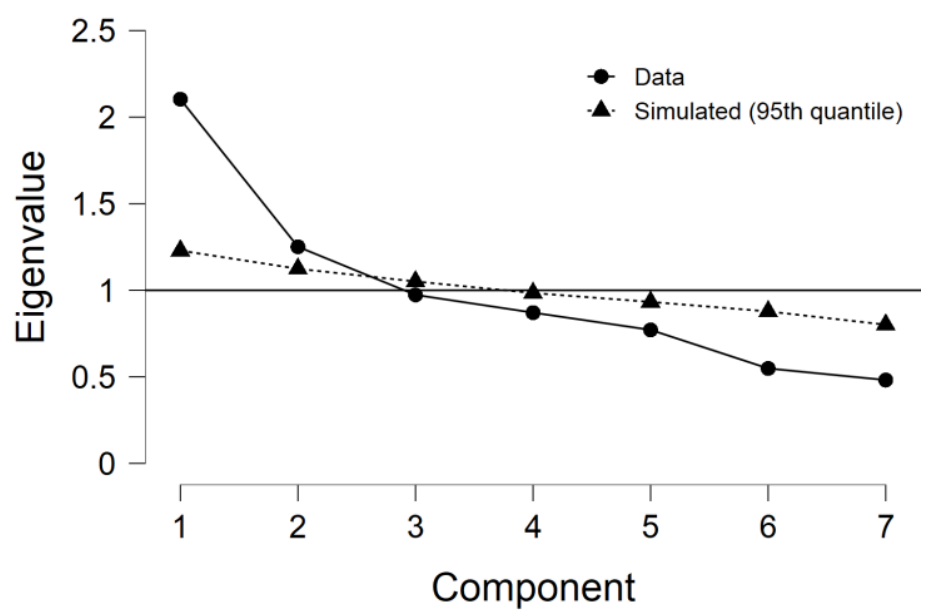

Source: Authors' work

Importance of brand identity and emotions

For the survey question on whether respondents believe that brand identity influenced by emotions is of immense importance in developing national brand identity, $48 \%$ of respondents agree, and $31 \%$ of respondents strongly agree (in total $79 \%$ ) with the statement which suggests primarily positive attitude.

Table 7

Opinion on the importance of brand identity and emotions

\begin{tabular}{llllll}
\hline Elements & $\begin{array}{l}1 \text { - Strongly } \\
\text { disagree }\end{array}$ & $\begin{array}{l}2- \\
\text { Disagree }\end{array}$ & $\begin{array}{l}3 \text { - Neither } \\
\text { agree nor } \\
\text { disagree }\end{array}$ & $\begin{array}{l}\text { Agree } \\
\text { agree }\end{array}$ & $\begin{array}{l}\text { 5-Strongly } \\
\text { agree }\end{array}$ \\
\hline $\begin{array}{l}\text { Q8. Brand identity influenced } \\
\text { by emotions is of immense } \\
\text { importance in the } \\
\text { development of national } \\
\text { brand identity }\end{array}$ & $1 \%$ & $2 \%$ & $18 \%$ & $48 \%$ & $31 \%$ \\
$\begin{array}{l}\text { Q9. The brand identity of } \\
\text { Croatia should be liked first } \\
\text { by Croatian residents than by } \\
\text { foreign tourists }\end{array}$ & $3 \%$ & $11 \%$ & $21 \%$ & $37 \%$ & $28 \%$ \\
\hline \begin{tabular}{l} 
Source: Authors Work \\
\hline
\end{tabular} & & & & \\
\hline
\end{tabular}

Source: Authors' work

Table 8 presents the results of the Shapiro-Wilk test for variables Q8 and Q9, indicating that the distribution of the variables is not following a normal distribution.

Table 8

Shapiro-Wilk test for variables Q1-Q7

\begin{tabular}{lll}
\hline & Q8 & Q9 \\
\hline Shapiro-Wilk & 0.828 & 0.869 \\
P-value of Shapiro-Wilk & $<.001^{* *}$ & $<.001^{* *}$ \\
\hline Note: & ** statistically significant at $1 \%$ \\
Source: Authors' work &
\end{tabular}


Table 9 presents the descriptive statistics for variables Q8 and Q9. A higher grade was given to variable Q8 than Q9. Dispersion is moderate across all variables, with the coefficients of variation ranging from $20.0 \%$ to the highest value of $28.6 \%$. Data distributions are skewed to the left for all the variables.

Table 9

Descriptive statistics for variables Q8 and Q9

\begin{tabular}{|c|c|c|}
\hline & Q8 & Q9 \\
\hline Valid & 330 & 330 \\
\hline Mean & 4.052 & 3.767 \\
\hline Median & 4.000 & 4.000 \\
\hline Std. Deviation & 0.811 & 1.079 \\
\hline Variation coefficient & $20,0 \%$ & $28,6 \%$ \\
\hline Skewness & -0.749 & -0.678 \\
\hline Std. Error of Skewness & 0.134 & 0.134 \\
\hline Kurtosis & 0.849 & -0.226 \\
\hline Std. Error of Kurtosis & 0.268 & 0.268 \\
\hline Shapiro-Wilk & 0.828 & 0.869 \\
\hline P-value of Shapiro-Wilk & $<.001$ & $<.001$ \\
\hline Minimum & 1.000 & 1.000 \\
\hline Maximum & 5.000 & 5.000 \\
\hline
\end{tabular}

Source: Authors' work

\section{Correlation analysis}

The correlation matrix indicates the weak correlation among the observed variables (Table 10). The Spearman correlation has been applied since the data is not following normal distribution (see Table 2). Observed correlations, which are statistically significant, are relatively weak, ranging from 0.143 to 0.348 .

Table 10

Spearman's Correlations of variables Q1 to Q7

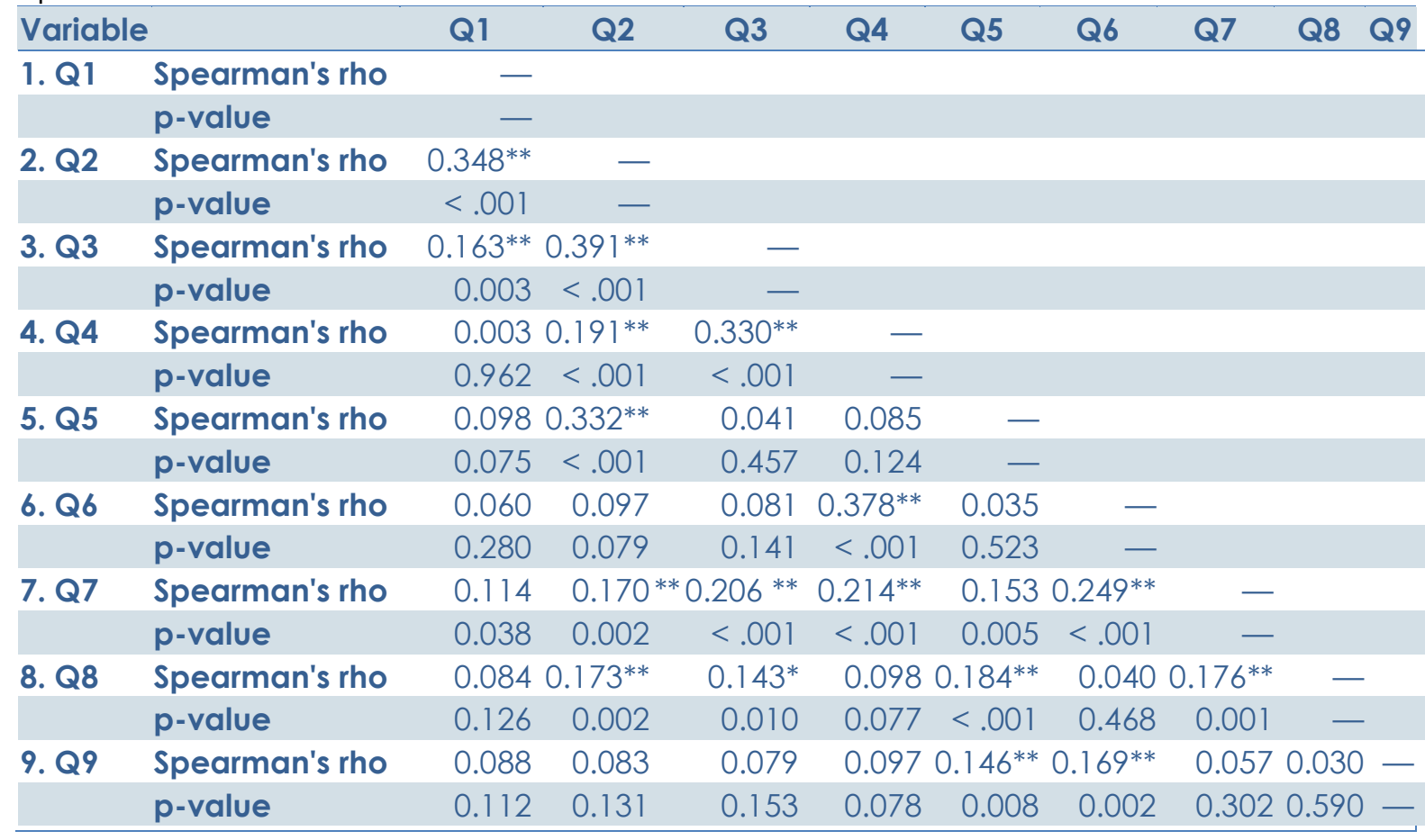

Note: ${ }^{* *}$ statistically significant at $1 \%, * 5 \%$

Source: Authors' work 


\section{Structural equation modeling}

Structural equation modeling has been conducted to test two research propositions $\mathrm{RP} 1$ and RP2.

The variables Q1 measure emotional elements of brand identity, Q2, Q3, and Q5, while formal aspects of brand identity are measured by the variables Q4, Q6, and Q7, as indicated by the principal component analysis. Two models were developed, one for each research proposition. The equations for the two models are presented in Table 11. Latent variables in each of the models are $\mathrm{fcl}$ and fc2

Table 11

Structural equation modeling codes applied in JASP

\begin{tabular}{ll}
\hline RP1: Dependent Q8 & RP2; Dependent Q9 \\
\hline \# measurement model & \# measurement model \\
\# latent variable of emotional elements & \# latent variable of emotional elements \\
$\mathrm{fC} 1=\sim \mathrm{Q} 1+\mathrm{Q} 2+\mathrm{Q} 3+\mathrm{Q} 5$ & $\mathrm{fCl}=\sim \mathrm{Q} 1+\mathrm{Q} 2+\mathrm{Q}$ + Q5 \\
\# latent variable of formal elements & \# latent variable of formal elements \\
$\mathrm{fC2}=\sim \mathrm{Q} 4+\mathrm{Q6}+\mathrm{Q7}$ & $\mathrm{fC2}=\sim \mathrm{Q} 4+\mathrm{Q6}+\mathrm{Q7}$ \\
\# regressions & \# regressions \\
$\mathrm{Q8} \sim \mathrm{fc} 1+\mathrm{fc} 2$ & Q9 $\sim \mathrm{fcl}+\mathrm{fc2}$ \\
\hline
\end{tabular}

Source: Authors' work

Tables 12 and 13 present the indicators of the model validity and goodness of fit. Model test against the baseline model is statistically significant at $1 \%$ for both models. The goodness of fit indices indicates the acceptable fit of the model since the indicators (CFI, RMSEA, and SMRM) are within the recommended values (Hair et al., 2010).

Table 12

The model test baseline model

\begin{tabular}{lrr}
\hline & RP1: Dependent Q8 & RP2; Dependent Q9 \\
\hline Minimum Function Test Statistic & 0.087 & 0.087 \\
$X^{2}$ & 57.133 & 57.722 \\
Degrees of freedom & 18.000 & 18.000 \\
$\mathbf{P}$ & $<.001^{* * *}$ & $<.001^{* * *}$ \\
\hline
\end{tabular}

Note: ${ }^{* *}$ statistically significant at $1 \%$

Source: Authors' work

Table 13

The goodness of fit indices

\begin{tabular}{llll}
\hline & RP1: Dependent Q8 & RP2; Dependent Q9 & Recommended values \\
\hline $\begin{array}{l}\text { Comparative Fit } \\
\text { Index (CFI) }\end{array}$ & 0.847 & 0.843 & $>0.9-$ very good \\
RMSEA & 0.081 & & $>0.8$ - good \\
& & 0.082 & $<0.08-$ very good \\
SRMR & 0.059 & 0.060 & $<0.10-$ good \\
& & & $<0.08-$ very good \\
& & & $<0.10-$ good \\
\hline
\end{tabular}

Source: Authors' work

Table 14 presents the factor loadings, which are higher than 0.4 for all the elements of the latent variables ( $\mathrm{fcl}$ and $\mathrm{fc} 2$ ). 
Table 14

Parameter estimation

\begin{tabular}{llcccccccc}
\hline & \multicolumn{3}{c}{ RP1: Dependent Q8 } & \multicolumn{5}{c}{ RP2; Dependent Q9 } \\
\hline & & est & se & $z$ & $P$ & est & se & Z & P \\
fc1 & Q1 & 1.000 & 0.000 & & & 1.000 & 0.000 & \\
fc1 & Q2 & 1.532 & 0.327 & 4.689 & $<.001^{* *}$ & 1.639 & 0.367 & 4.466 & $<.001^{* *}$ \\
fc1 & Q3 & 1.555 & 0.325 & 4.778 & $<.001^{* *}$ & 1.506 & 0.316 & 4.765 & $<.001^{* *}$ \\
fc1 & Q5 & 0.474 & 0.124 & 3.827 & $<.001^{* *}$ & 0.478 & 0.123 & 3.867 & $<.001^{* *}$ \\
fc2 & Q4 & 1.000 & 0.000 & & & 1.000 & 0.000 & & \\
fc2 & Q6 & 0.899 & 0.183 & 4.923 & $<.001^{* *}$ & 0.982 & 0.193 & 5.089 & $<.001^{* *}$ \\
fc2 & Q7 & 0.611 & 0.132 & 4.627 & $<.001^{* *}$ & 0.607 & 0.130 & 4.655 & $<.001^{* *}$ \\
\hline
\end{tabular}

Note: ${ }^{* *}$ statistically significant at $1 \%$

Source: Authors' work

Table 15

The regression equation for RP1 and RP2 models RP1: Dependent Q8 RP2; Dependent Q9

\begin{tabular}{llcccccccc}
\hline & & est & se & $z$ & $P$ & est & se & $z$ & $P$ \\
Q8 & $f c 1$ & 0.419 & 0.183 & 2.290 & $0.022^{*}$ & 0.034 & 0.218 & 0.154 & 0.877 \\
Q9 & fc2 & 0.096 & 0.093 & 1.035 & 0.301 & 0.329 & 0.130 & 2.533 & $0.011^{* *}$ \\
\hline
\end{tabular}

Note: ${ }^{* *}$ statistically significant at $1 \%$

Source: Authors' work

Table 15 presents the regression equations for RP1 and RP2 models. In the first SEM model, the fcl has a positive statistically significant impact at the variable Q8, while fc2 does not significantly impact the same variable. In the second SEM model, the fc2 has a positive statistically significant impact at the variable Q9, while fcl does not considerably affect the same variable. Figure 2 presents the path diagram for $\mathrm{RP} 1$ and Figure 3 for the RP2 model.

Figure 2

Path diagrams for RP1 model

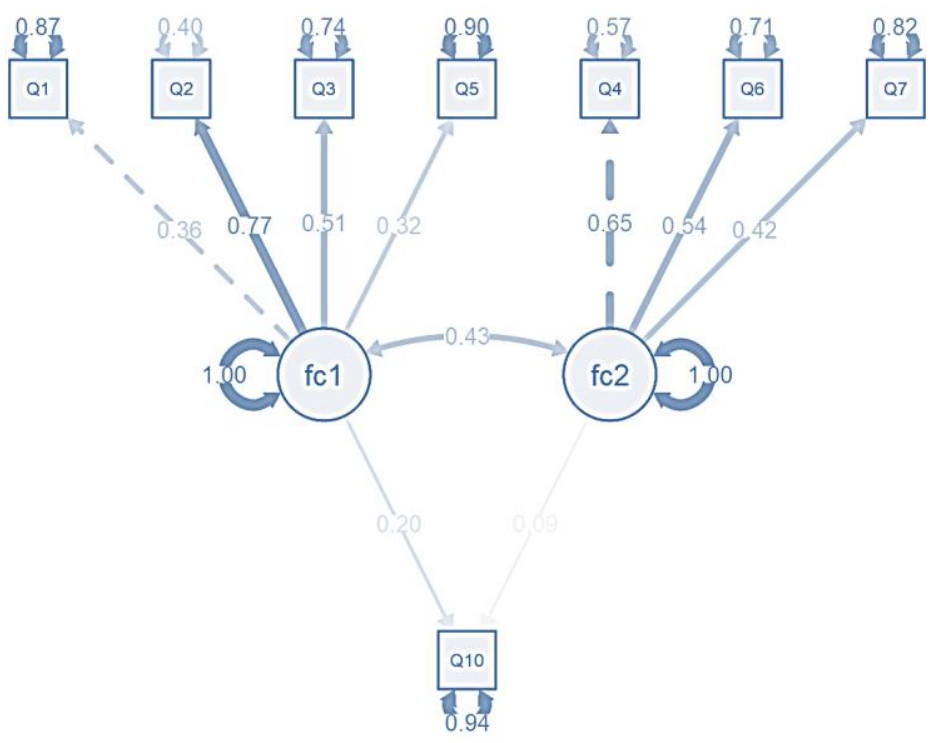

Source: Authors' work 
Figure 3

Path diagrams for RP2 model

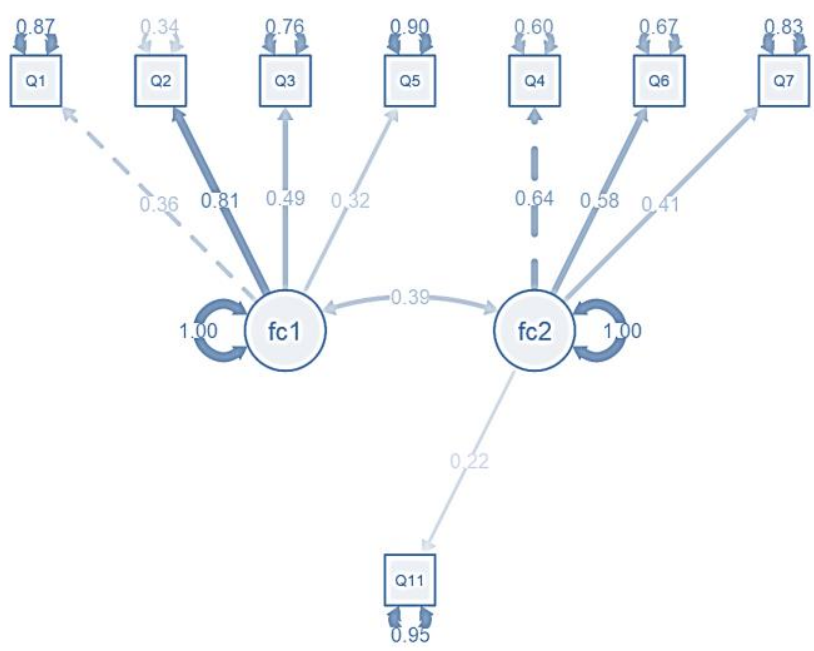

Source: Authors' work

\section{Conclusion}

As one of the emerging countries on the internal map of tourism, Croatia has a high potential to develop an adequate national brand. By defining the most specific elements, innovative and friendly design, and continuous and consistent work, the Croatian branding moves through the decisions of all society bodies: government decisions, tourist stakeholders, residents, and foreign tourists. Croatia can compete globally through its natural beauties, innovative and talented individuals, technological possibilities, and friendly and secure atmosphere. National branding in all dimensions of national competence can make Croatia a powerful and successful brand and point out Croatia's diversity of opportunities and hidden potentials.

This research aimed to determine the elements of brand identity that respondents mostly associate with Croatia and examine their opinion on developing the Croatian brand identity that enables brand positioning.

The respondents of the student population differentiated the elements that, in their opinion, represented the nation the most, which are natural landscape, food, and buildings. In contrast, at least factors that contribute to brand identity are logo/symbol and fashion. Principal component analysis indicated that these elements could be divided into emotional aspects of brand identity and formal brand identity elements.

Two research propositions were tested. The first presumes that the emotional elements of brand identity will be more connected to the belief that the brand identity that influences emotions is essential in creating a national brand identity than the formal elements of brand identity (RP1). The second presumes that the traditional aspects of brand identity will be more connected to the belief that the brand identity of Croatia should be liked first by the inhabitants of Croatia and only then by foreign tourists than the emotional elements of brand identity (RP2). The research propositions were tested using structural equation modeling. Both research propositions were confirmed.

Since this research has been conducted on the sample of Croatian students, future analysis should be performed on the sample of tourists who visit Croatia and 
those who visit other countries considered the direct competitors of Croatia as the destination.

\section{References}

1. American Marketing Association (2021), "Branding", available at: https://www.ama.org/topics/branding/ (30 July 2021)

2. Aronczyk, M. (2008), "Living the Brand: Nationality, Globality, and the Identity Strategies of Nation Branding Consultants", International Journal of Communication 2, Vol. 2, pp. 41-65.

3. Barnett, M. L., Jermier, J. M., Lafferty, B. A. (2006), "Corporate reputation: The definitional landscape", Corporate reputation review, Vol. 9 No. 1, pp. 26-38.

4. Brand Finance, (2020), "Nation Brands 2020", available at: https://brandirectory.com/download-report/brand-finance-nation-brands-2020-

preview.pdf (10 August 2021)

5. Dinnie, K. (2016), Nation branding: Concepts, issues, practice, Routledge, Burlington.

6. Fajardo, T. M., Zhang, J., Tsiros, M. (2016), "The contingent nature of the symbolic associations of visual design elements: The case of brand logo frames", Journal of consumer research, Vol. 43 No. 4, pp. 549-566.

7. Fan, Y. (2006), "Branding the nation: What is being branded?", Journal of vacation marketing, Vol. 12 No. 1, pp. 5-14.

8. Fombrun, C. J. (2001), Corporate reputation as economic assets, in Hitt, M. A., Freeman, R. E., Harrison, J. S. (Eds.), The Blackwell Handbook of Strategic Management, Blackwell Publishers, Malden.

9. Fombrun, C., Van Riel, C. (1997), "The reputational landscape", Corporate reputation review, Vol. 1, pp. 5-13.

10. Grgić, D. (2012), "Corporate reputation index: empirical research in banking sector", Market-Tržište, Vol. 24 No. 1, pp. 23-45.

11. Hair, J. F., Celsi, M., Ortinau, D. J., Bush, R. P. (2010), Essentials of marketing research, Vol. 2, McGraw-Hill/ Irwin, New York.

12. Handayani, B., Rashid, B. (2013), "Conceptualisation of Nation Brand Image", International Journal of Management Studies, Vol. 20 No. 1, pp. 165-183.

13. Ipsos (2020a), "Anholt Ipsos Nation Brands Index", available at: https://www.ipsos.com/sites/default/files/20-03-60_anholt-ipsos_place-

branding.pdf? utm_source $=$ email\&utm_campaign $=1071746 \& u t m \_c o n t e n t=s i d e b a r P r o d u c$ tSheet (30 July 2021)

14. Ipsos (2020b), "Nation Brands Index 2020", available at: https://www.ipsos.com/svse/nation-brand-index-2020 (10 August 2021)

15. Johnson, J. (2020), "Visual identity: everything you need to know about this essential aspect of branding ", available at: https://99designs.com/blog/logo-branding/visualidentity/ (25 April 2021)

16. Kang, M., Yang, S. U. (2010), "Comparing effects of country reputation and the overall corporate reputations of a country on international consumers' product attitudes and purchase intentions", Corporate Reputation Review, Vol. 13 No. 1, pp. 52-62.

17. Kervyn, N., Fiske, S. T., Malone, C. (2012), "Brands as intentional agents framework: How perceived intentions and ability can map brand perception", Journal of Consumer Psychology, Vol. 22 No. 2, pp 166-176.

18. Kesić, T., Rajh, S. P., Vlašić, G. (2004), "Country Branding as a Global Competitive Marketing Strategy", An Enterprise Odyssey International Conference Proceedings, pp. 1740-1755.

19. Kesić, T., Vlašić, G., Jakeljić, M. (2010), "Destination image mechanisms in transitional economies", 39th European Marketing Academy (EMAC) Conference, Copenhagen, Denmark.

20. Lee, K., Carter, S. (2009), Global Marketing Management, Oxford University Press, Oxford.

21. Loo, T., Davies, G. (2006), "Branding China: The ultimate challenge in reputation management? ", Corp Reputation Review, Vol. 9, pp. 198-210. 
22. Martín, H. S., Bosque, I. A. R. (2008), "Exploring the cognitive-affective nature of destination image and the role of psychological factors in its formation", Tourism Management, Vol. 29, pp. 263-277.

23. Papp-Váry, Á. (2018), "A Successful Example of Complex Country Branding: The 'EEstonia'Positioning Concept and Its Relation to the Presidency of the Council of the EU", Acta Universitatis Sapientiae, European and Regional Studies, Vol. 14, pp. 87-115.

24. Passow, T., Fehlmann, R., Grahlow, H. (2005), "Country reputation - From measurement to management: The case of Liechtenstein", Corporate Reputation Review, Vol. 7 No. 4, pp. 309-326.

25. Roberts, P. W., Dowling, G. R. (2002), "Corporate reputation and sustained superior financial performance", Strategic Management Journal, Vol. 23 No. 12, pp. 1077-1093.

26. Roth, K. P. Z., Diamantopoulos, A., Montesinos, M. Á. (2008), "Home country image, country brand equity and consumers' product preferences: an empirical study", Management International Review, Vol. 48 No. 5, pp. 577-602.

27. Stoimenova, B. (2017), "Visual Brand Identity Design", Conference: Marketing and Design.

28. Volos, V. (2019), "Germany Retains Top "Nation Brand" Ranking, France and Canada Emerge to Round Out the Top Three", available at: https://www.ipsos.com/en-us/newspolls/Germany-Retains-Top (10 August 2021)

29. Zhouxiang, L. (Ed.) (2020), Chinese National Identity in the Age of Globalisation, Palgrave Macmillan.

\section{About the authors}

Sanja Seljan is a full professor, Ph.D. in Information and Communication Sciences, Faculty of Humanities and Social Sciences, University of Zagreb. Her research interests are data analysis and machine learning, information extraction, knowledge discovery, text mining, language technologies in business, machine translation, natural language processing. She was a project manager of the national scientific project funded by MZOS, five university grants, and participated in 9 international and national projects. She gave four invited speeches in the European Commission and European Parliament, was a guest lecturer, and invited speaker at European and world universities and international conferences. She is a member of international conference program committees and review boards for international journals. The author can be contacted at email sanja.seljan@ffzg.hr

Sara Horvat is a student of Information sciences and Sociology and a graduate student of teaching-oriented study of Informatics at the Faculty of Humanities and Social Sciences, University of Zagreb. Her research interests are creative teaching, brand identity and branding, organization of information, information analysis, and teaching methods in information science. The author can be contacted at email sahorvał@ffzg.hr

Berislava Starešinić, Ph.D., is Director for Affluent Segment Development, Function of Affluent Clients, Retail group, Privredna Banka Zagreb. Her research interests include banking, organizational behavior, banking reputation, and direct and digital channels. The author can be contacted at bstaresinic@pbz.hr 